\title{
Research on Exam System Reform in the University in China
}

\author{
Ping Guo * \\ School of Economics and Management, \\ Shijiazhuang Tiedao University \\ Shijiazhuang, China \\ guo_gp@163.com \\ * Corresponding Author
}

\author{
Xinning Zhang \\ School of Economics and Management, \\ Shijiazhuang Tiedao University \\ Shijiazhuang, China \\ zhxn@sohu.com
}

\begin{abstract}
The paper is based on position, objectives, functions of university exams, combined with collaborative teaching and testing principles examination system, studies the rationalization ideas of the university examination system reform. Reforms include examination content selection, examination system settings, scientific assigning topic system, teaching evaluation system, scientific scoring system, test library building and separation of teaching and testing, etc.
\end{abstract}

Keywords- university; exam system; function; reform;evaluation

\section{INTRODUCTION}

For university students, a group receiving higher education, examination is an important link of the learning process. [1-2]But at present, cheating appearance often happens in the campus, and becoming even more serious. Whenever courses final exams, or English CET 4 or CET 6, computer grade exam, more and more students shows special powers, from the "cheating alone" to cheating in a group. So how to reform the examination system, to promote quality education, to improve teaching quality, and to effectively prevent and reduce cheating has become an important part of the reform of the university examination system.

\section{THE CHARACTERISTICS OF THE UNIVERSITY EXAMINATION}

\section{A. The position for the university examination}

University examination is different from recruitment exam, [3]it is a course exam, testing the students the mastery condition of the basic concepts and knowledge at the end of a specialized course, the purpose is to test whether the students reach a certain level of knowledge and have the corresponding ability of professional course. The current university examination has deviated from the purpose and the starting point. Concrete form is that besides identifying the effect of learning, the exam was also given a certain selection function, such as excellent student appraising, the scholarship evaluation and walks graduate, etc. which are closely related with the test scores. This makes the students turn the study target in to exam target, and some problems have been emerged. Because in this case, the students are concerned with the examination results and pay attention to the selection function of examination, they are no longer to learn for knowledge and ability but for score. [4]We believe that selection function should be weakened in the university exams, and the test should return to the original design, which means the examination should be regarded as an essential link in the teaching process, and an indispensable means for improving the teaching quality.

\section{B. The objectives for the university test}

The purpose of higher education firstly is to impart knowledge and secondly to develop the students' ability and improve the comprehensive quality of students, particularly to develop students' self-development and innovation ability. The exam is an effective tool to promote students' all-round development, to improve the quality, and to realize the purpose of education, which is the sensible resolution for the basis and the end of modern examination. Thus, students, teachers and administrators must return the exams to the right track such as checking teaching effectiveness, and promoting teaching and learning level, consolidating the knowledge, improving skills and quality. The exam should not only pay attention to the study results, but also the study process; Effectiveness of the university exams is reflected in multidimensional, comprehensive and practical aspects. When exams become an element under background of promoting education reform environment, it may lead to education change, the exam will obtain substantial improvement effect only in the case of broad participation of the education field.[5]

\section{The function of the university examination system}

The function of university examination should be identification, evaluation, guidance and others. The purpose of social qualification examination is to award the vocational qualification or social qualification through the exam, which means that someone who pass the exam reach a certain professional level or qualifications. This kind of exam only has the identification function of qualifications (level). Besides the identification function, university course examination also has the function of evaluation and guidance. On the one hand, examination helps students to master and apply the knowledge; on the other hand, to examine the effect of classroom teaching, teaching quality, to find and solve the problems in teaching by the feedback information from the exam, so as to evaluate the teaching activities. [6]If the test adopts flexible and varied methods, exam content is comprehensive and analytical, this will lead the students to develop their potential ability, arouse 
their consciousness of initiative innovation and capabilities of analysis and solve problems.

\section{EXAM S YSTEM PRINCIPLE OF TEACHING- EXAMINATION S YNERGY}

As a tool of higher education, university examination does not exist abstractly and isolated, it's a kind of education activity or education means under a certain education idea and education principle. Examination is not only to test the students specific learning situation, but as a part of teaching activity of certain courses. We need exam, because we can check and promote the implementation of course objective system by exam. As a teaching method, the basis of exam system design is to achieve the curriculum target, the curriculum target is the fundamental reason, design basis and evaluation principle of all relevant teaching activities. The design and content of course target is the catabolic phase of the university teaching target, according to the national higher education ideas. The relationship of national higher education idea, the university education teaching target, curriculum and examination is just as followed.

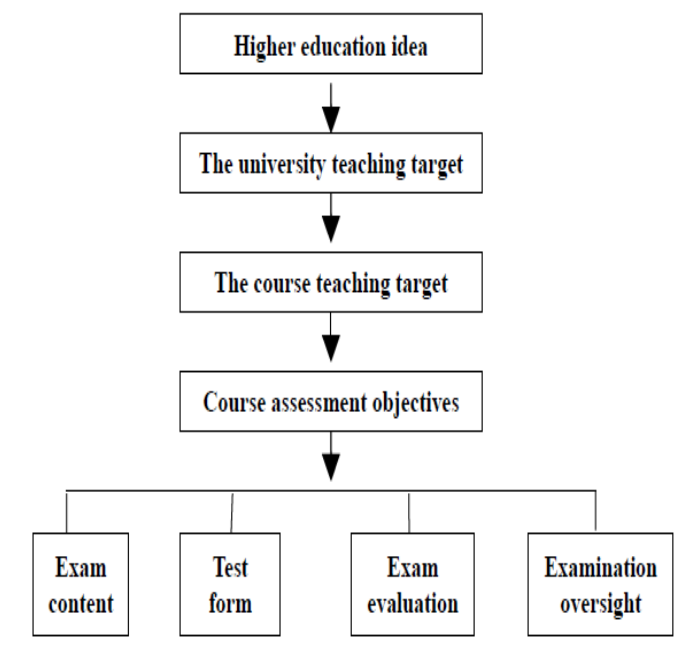

Figure 1. The relationship of national higher education idea, the university education teaching target, curriculum and examination

\section{COURSE EXAM CONTENT SELECTION}

\section{A. Teaching goal setting}

If the study motivation is to the learning knowledge, seldom student to cheat at the examination, and if the study motivation is the outside pressure, the students have exam cheating motivation. Therefore, to reduce the cheating motivation and behavior, it is important to enhance students' interest in learning, which asks teachers to change teaching content and teaching methods. Teachers teaching content and teaching methods, enhancing students' interest in learning, and inspiring students learning motivation, all of this can't do without teaching objectives design.[7] In the fifties of last century, taxonomy of the cognitive domain was developed in United States, clearly illustrated the inextricable connection between the teaching objectives and exam questions preparation to assess, and divided the educational objectives into three systems: cognition, emotion and social fields.

\section{B. Two-way detail table}

Teaching objectives guide the center of effective teaching, and also guide the examinations. When teachers prepare the exam questions, they should not only consider the involved subject content, but also take into account the students' mental processes aroused by these contents. Generally, we put the content into two-dimensional table - two-way detail table. The row content of the double detail table is the teaching target keywords (mental processes), the question number and weights assigned to each column reflects the important degree of the mental process. The column content of two-way detail table is the subject content, the weights assigned to each theme is based on the teachers' attention to the topic. Each unit in the table is the intersection point of student mental process and a specific subject topic, table 1 take the regression model in the course of econometrics as an example to show this two-way detail table.

TABLE 1. TWO-WAY DETAIL TABLE O REGRESSION MODEL

\begin{tabular}{|c|c|c|c|c|c|}
\hline \multirow[b]{2}{*}{ Theme } & \multicolumn{4}{|c|}{ Request for test paper and pen } & \multirow{2}{*}{$\begin{array}{c}\text { Creative } \\
\text { application } \\
\text { of } \\
\text { measureme } \\
\text { nt methods } \\
\text { to solve } \\
\text { practical } \\
\text { problems }\end{array}$} \\
\hline & $\begin{array}{l}\text { Memory and } \\
\text { understanding }\end{array}$ & $\begin{array}{l}\text { Analysis } \\
\text { and } \\
\text { application }\end{array}$ & $\begin{array}{l}\text { Synthetic } \\
\text { application }\end{array}$ & $\begin{array}{l}\text { Evaluation } \\
\text { of the } \\
\text { measureme } \\
\text { nt method }\end{array}$ & \\
\hline $\begin{array}{l}\text { Summary of } \\
\text { regression } \\
\text { analysis }\end{array}$ & $3 \%$ & $5 \%$ & $1 \%$ & $1 \%$ & \multirow{6}{*}{$\begin{array}{c}\text { Each } \\
\text { student use } \\
\text { the method } \\
\text { of } \\
\text { measureme } \\
\text { nt to study } \\
\text { practical } \\
\text { problems } \\
\text { and submit } \\
\text { the } \\
\text { research } \\
\text { paper }\end{array}$} \\
\hline $\begin{array}{c}\text { The basic } \\
\text { hypothesis of unary } \\
\text { linear regression } \\
\text { model }\end{array}$ & $3 \%$ & $5 \%$ & $1 \%$ & $1 \%$ & \\
\hline $\begin{array}{l}\text { A linear regression } \\
\text { model parameter } \\
\text { estimation }\end{array}$ & $3 \%$ & $5 \%$ & $2 \%$ & $2 \%$ & \\
\hline $\begin{array}{l}\text { To test a linear } \\
\text { regression model }\end{array}$ & $3 \%$ & $5 \%$ & $2 \%$ & $2 \%$ & \\
\hline $\begin{array}{l}\text { To predict a linear } \\
\text { regression model }\end{array}$ & $3 \%$ & $5 \%$ & $2 \%$ & $2 \%$ & \\
\hline $\begin{array}{l}\text { Examples and time } \\
\text { sequence problem }\end{array}$ & $5 \%$ & $5 \%$ & $2 \%$ & $2 \%$ & \\
\hline & $20 \%$ & $30 \%$ & $10 \%$ & $10 \%$ & $30 \%$ \\
\hline
\end{tabular}

\section{Scoring rules table}

Scoring rules table is very useful in the design of teaching, and should be made before the start of the teaching, maximize their potentiality, so as to achieve the following objectives: (1)to make the teachers consider teaching objectives more clearly; (2) to ensure that the test goal is to achieve the teaching content; (3) to make teachers pay attention to the teaching content and cultivate ability; (4) to connect the examination evaluation and the teaching contents; (5) to let the students know what content should be mastered; (6) to allow students to participate in more effective self evaluation.[8]

Usually the examination evaluation rules are applicable to fuzzy teaching objectives (such as creative ability evaluation), therefore it often as a list form, using analytic rating, so that we can easily achieve greater reliability and validity; similarly, it also provide effort direction for each 
student. The scoring rules for student research paper is as followed.

TABLE 2. STUDENT RESEARCH PAPERS SCORING RULES

\begin{tabular}{|c|c|c|c|c|c|}
\hline \multirow{7}{*}{$\begin{array}{l}\text { Review } \\
\text { comments }\end{array}$} & Title & 1.On topic & \multicolumn{3}{|c|}{ 2.Off the point, should be replaced: } \\
\hline & Abstract & 1.Accurate & \multicolumn{3}{|c|}{ 2.The expression is not complete, should add: } \\
\hline & Structure & $\begin{array}{l}\text { 1.Precise and } \\
\text { clear }\end{array}$ & $\begin{array}{c}2 . \text { Not } \\
\text { rigorous }\end{array}$ & $\begin{array}{l}\text { 3.Chapter } \\
\text { mesh messy }\end{array}$ & \\
\hline & $\begin{array}{l}\text { State the } \\
\text { opinion }\end{array}$ & 1.Correct & $\begin{array}{l}\text { 2.Argument } \\
\text { is not } \\
\text { sufficient }\end{array}$ & $\begin{array}{l}\text { 3.Part of } \\
\text { derivation is } \\
\text { incorrect }\end{array}$ & \\
\hline & $\begin{array}{l}\text { Language } \\
\text { expression }\end{array}$ & $\begin{array}{l}\text { 1.Clear and } \\
\text { smooth }\end{array}$ & $\begin{array}{l}\text { 2. Repeat } \\
\text { lengthy }\end{array}$ & 3.Poor logic & \\
\hline & $\begin{array}{c}\text { Confidential } \\
\text { content }\end{array}$ & 1.Not involved & $\begin{array}{l}\text { 2.Involved } \\
\text { and should } \\
\text { not published }\end{array}$ & $\begin{array}{l}\text { 3.Parts } \\
\text { involved and } \\
\text { should } \\
\text { modified }\end{array}$ & \\
\hline & $\begin{array}{l}\text { Factual } \\
\text { material }\end{array}$ & $\begin{array}{c}\text { 1.Based on } \\
\text { reliable }\end{array}$ & $\begin{array}{l}\text { 2.There are } \\
\text { inaccuracies }\end{array}$ & 3.Plagiarism & \\
\hline \multirow[t]{2}{*}{$\begin{array}{c}\text { Evaluation } \\
\text { opinion }\end{array}$} & $\begin{array}{c}\text { Academic } \\
\text { value }\end{array}$ & $\begin{array}{l}\text { 1. Originality,va } \\
\text { lue on the } \\
\text { development of } \\
\text { the subject }\end{array}$ & $\begin{array}{l}\text { 2.Improved, } t \\
\text { here is } \\
\text { reference } \\
\text { value for } \\
\text { teaching and } \\
\text { scientific } \\
\text { research }\end{array}$ & $\begin{array}{l}\text { 3. Diplicate } \\
\text { the work of } \\
\text { others, have } \\
\text { no practical } \\
\text { value }\end{array}$ & \\
\hline & $\begin{array}{c}\text { Comprehensi } \\
\text { ve } \\
\text { evaluation }\end{array}$ & $\begin{array}{c}\text { 1.Advanced } \\
\text { level }\end{array}$ & $\begin{array}{c}\text { 2.A higher } \\
\text { level }\end{array}$ & $\begin{array}{c}\text { 3.The medium } \\
\text { level }\end{array}$ & $\begin{array}{c}\text { 4.The general } \\
\text { level }\end{array}$ \\
\hline
\end{tabular}

\section{SETTING THE EXAMINATION SYSTEM}

\section{A. Scientific Assigning topic System}

The purpose of reforming the examination is to guide students on the basis of mastering theory, knowledge and skills, to cultivate innovative consciousness and innovative ability. Whether the objective or subjective questions of examination contents, should be avoided excessive focus on mechanical memory and representation of the knowledge. Topic assigned should provide students with more opportunity to explore, and encourage students to think independently, to answer the questions full of personality and creativity, and make innovation as an important index to measure the quality of the answer. The author thinks that the examination content should be based on comprehensive topic assigned, topic assigned focuses on a deep understanding of the knowledge, and analysis and comparison and mastery through a comprehensive study of the subject, at the same time, the student can put forward their own solutions to the problems, consciously by exam to guide students to expand their knowledge and train the ability of solving problem. For the applicationoriented subjects, we should minimize the test content, and through the practice to test their mastery of knowledge and hands-on ability. Teachers also need to overcome the boredom and easy way psychology of grading work, enhance the sense of responsibility and mission. Teachers often ignore the important guiding role of examination evaluation for students. In fact, each answer sheet of student is a lively life, and it is also a variety of unique thinking. [9] The teacher can't delineate their score basis to the restrictions and fetters of book content. On the base of knowledge mastery to encourage creating something new and original, to query and boldly put forward their views and opinions. So the appraisal content includes not only the basic knowledge, basic theory and basic skills of course, but also the comprehensive ability and quality of raising questions, analyzing problems, and solving problems, stresses the importance of evaluating students' innovative consciousness and innovative ability. The examination content should have key, and certain practical significance.

\section{B. Teaching Evaluation System}

Drawing on the experience of mature evaluation index in American, France and Germany, combining the general undergraduate education fact in China, the learning quality process assessment of university student can focus on the following aspects as shown in table 3 .

TABLE 3. TEACHING EVALUATION FORM

\begin{tabular}{|c|c|c|c|}
\hline $\begin{array}{c}\text { Evaluation } \\
\text { object }\end{array}$ & $\begin{array}{c}\text { Evaluation } \\
\text { project }\end{array}$ & Meas urement indicators & $\begin{array}{l}\text { Evaluation } \\
\text { form }\end{array}$ \\
\hline $\begin{array}{l}\text { Teacher } \\
\text { evaluate } \\
\text { students }\end{array}$ & $\begin{array}{l}\text { Active } \\
\text { learning } \\
\text { attitude of } \\
\text { students }\end{array}$ & $\begin{array}{l}\text { The class attendance; the frequency of } \\
\text { answering questions; the role in group } \\
\text { disc ussion and the number of speeches; the } \\
\text { working completion after chass; the reading } \\
\text { on specified material ( reading notes); the } \\
\text { number of the student inquiry of the } \\
\text { problem after class and its difficult de gree }\end{array}$ & $\begin{array}{l}\text { Excellent, } \\
\text { good, poor, } \\
\text { fuzzy grade }\end{array}$ \\
\hline $\begin{array}{l}\text { Students } \\
\text { mutual } \\
\text { evaluation }\end{array}$ & $\begin{array}{l}\text { The level of } \\
\text { cooperation } \\
\text { between } \\
\text { students } \\
\text { learning }\end{array}$ & $\begin{array}{l}\text { Group participation; whether to partic ipate } \\
\text { in a research activity voluntarily; whether } \\
\text { do you want to share own ideas and } \\
\text { research ideas with other students; whether } \\
\text { to overcome the difficulties with other } \\
\text { students in the extracurricular practice } \\
\text { activities }\end{array}$ & $\begin{array}{l}\text { Excellent, } \\
\text { good, poor, } \\
\text { fuzzy grade }\end{array}$ \\
\hline \multirow[b]{2}{*}{$\begin{array}{c}\text { Self } \\
\text { evaluation }\end{array}$} & $\begin{array}{l}\text { The } \\
\text { challenge } \\
\text { degree of } \\
\text { learning }\end{array}$ & $\begin{array}{l}\text { Do you think what is the biggest difficulty } \\
\text { or confision in the learning process of this } \\
\text { course? This difficulty is resolved? How to } \\
\text { solve? If there are other unresolved } \\
\text { difficulties? }\end{array}$ & Questionnaire \\
\hline & $\begin{array}{l}\text { The rich } \\
\text { degree of } \\
\text { Learning } \\
\text { experience }\end{array}$ & $\begin{array}{l}\text { Whether do you have the sense of } \\
\text { achievement in the process of learning this } \\
\text { course? Apart from the textbook } \\
\text { knowledge learning. Also to deepen their } \\
\text { knowledge and understanding through } \\
\text { other ways? Such as practice, community } \\
\text { activities }\end{array}$ & Questionnaire \\
\hline $\begin{array}{l}\text { Students' } \\
\text { evaluation } \\
\text { of teacher }\end{array}$ & $\begin{array}{l}\text { The level of } \\
\text { teacher-stude } \\
\text { nt interaction }\end{array}$ & $\begin{array}{l}\text { Whether to discuss or to carry out } \\
\text { cooperative research with their teachers? } \\
\text { Talk about the knowled ge and ability get } \\
\text { from the teachers? }\end{array}$ & Questionnaire \\
\hline $\begin{array}{l}\text { Students' } \\
\text { evaluation } \\
\text { of school } 1\end{array}$ & $\begin{array}{l}\text { The support } \\
\text { degree of } \\
\text { campus } \\
\text { environment }\end{array}$ & $\begin{array}{c}\text { The attitude On campus environment and } \\
\text { their own harvest assessment during the } \\
\text { reading }\end{array}$ & Questionnaire \\
\hline
\end{tabular}

\section{Scientific scoring system}

Scoring is an important link in the examination, and plays an important role on the test quality and function. The students' score in one exam, only means his performance in this course exam, does not represent all of his ability in certain aspect. So we can't judge the students' intelligence level based on one test score. In fact, percentage grading system is a product of "knowledge gasping measurement", if we want to complete creative education, train innovative talents, we must reform the traditional scoring system. So we can adopt a more flexible way to score, based on the grading scoring system, according to the characteristics of the course, teaching objectives, teaching difficulty, etc. For example, to the subjective test questions and paper, we adopt relative score method and grading scoring method. To the objective test, Yes or no questions, multiple choice questions, we adopt accurate scoring method and quantitative evaluation 
method. At the same time, to comprehensivize students' grade score, put a certain proportion into the final exam, quizzes, social practice, learning discipline, classroom speeches. In the evaluation method, we not only pay attention to the test results, but also should focus on the students' thinking and the thinking process when they solve problems, and to encourage students to think boldly, explore diligent1y, for the novel, unique, creative, innovative answer, we should give bonus points. Allow students to restudy and retest, reselect the course, eliminate the negative effects that one examination decides everything. [10] Which makes teachers and students free from score fraction, and make great efforts into the teaching reform and fostering innovative abilities.

\section{To establish the database and implement the separation system of teaching and testing}

The separation of teaching and testing generally refers to separate the teaching and examination grading work in the process of teaching, and it is shared by different educators, so as to form a kind of constraint relationship between teaching and examination. Under the separation of teaching and examination system, the level and standard deviation away from teaching requirements and syllabus is smaller, and the depth and breadth, difficulty, discrimination, type layout of the test paper is moderate, so as to improve the teaching quality indicators of measuring test. The teaching and examination separation can effectively avoid students' cram for a test, and it can more objectively reflect the teaching effect, and also promote teachers in strict accordance with the syllabus, avoid the arbitrariness of teacher lectures, and promote the two way activities of teachers' leading role and students' main role, which is more fair and reasonable on the exam and seeking truth to reflect students' actual level. This separation is helpful to arouse the enthusiasm of both teaching and learning practice, the important way of teachingexamination separation is to set up test bank. [11] Test bank fundamentally overcome the disadvantages of traditional test, which is based on a scientific theory, generated by computer test, so as to make the examination has flexibility and science. The quality and quantity of test bank is the basis to expand of separation, and should constantly update and gradually improve in the dynamic situation, according to the change of the teaching content and target, at the same time, to make the test bank construction scientific, standardized, and modernized.

\section{ACKNOWLEDGMENT}

The paper is the section of the research results for the project "Breadth and depth teaching of "Money and Banking" under professional background", which is funded by Shijiazhuang Tiedao University Education Technology key project in Twelfth Five-Year Plan in 2014.

\section{REFERENCES}

[1] B. M. Patil "Comparative Study of Open Book Exam and Close Book Exam For VIIth Std.” Golden Research Thoughts, 2012,DOI: $10.9780 / 22315063$

[2] Mohammad A Sarrayrih,Mohammed Ilyas. "Challenges of Online Exam, Performance and problems for Online University Exam. " International Journal of Computer Science Issues, Vol. 10, Issue 1, No 1, January 2013,pp,439-443.

[3] Hong Junwei. "University Examination Ethics-- to the case of universities since the reform and opening in China" People's Press, Dec. 2014.Chinese.

[4] Paul Jarrod DeCarlo,Nouhad Rizk. "The Design and Development of an Expert System Prototype for Enhancing Exam Quality" International Journal of Advanced Corporate Learning, 2010, DOI: 10.3991/ijac.v3i3.1356

[5] Jana Hackathorn,Kathryn Cornell,April Garczynski,Erin Solomon"Examining exam reviews: A comparison of exam scores and attitudes" The Journal of Scholarship of Teaching and Learning, Vol. 12, No. 3, September 2012, pp. 78 - 87.

[6] Samiksha Nikam,B.T. Jadhav“Design and Development of Result Tool for University and University Exam and it's Performance Study" International Journal on Computer Science and Engineering Vol. 3 No. 11 November 2011,pp,3518-3524.

[7] Fan Liang, Chen Wenjun. "examination reform in the demand of training innovative talents". Education and Vocation, Vol.36, 2014, pp.190-191.Chinese.

[8] Fu Lei, Wang Xin."Study on examination reform of Universitys and universities". Intelligence, Vol. 20, 2015, pp. 111. Chinese.

[9] Bao Yihong, Meng Lin. "University examination reform in innovative talent training practice", Education Teaching Forum, Vol.49, Dec 2014,pp.158-159.Chinese.

[10] Wang Wan. "Reform of Undergraduate Curriculum assessment methods". Intelligence, Vol. 25, 2014, pp. 116. Chinese.

[11] Zeng Jin, Li Hujie."Thinking on the University Course Exam Reform Based on the the Modern Concept of Talents" . Science \& Technology Vision, Vol.4, 2015,pp.83.Chinese. 